\author{
ТЕКСТ Д. ХАРМСА КАК ОБЬЕКТ СОВРЕМЕННОГО \\ ЛИНГВИСТИЧЕСКОГО ИССЛЕДОВАНИЯ
}

\author{
(C) Лиана Ахметзянова
}

\title{
D. HARMS'S TEXT AS THE OBJECT OF MODERN LINGUISTIC RESEARCH
}

\begin{abstract}
Liana Akhmetzyanova
The article considers text in terms of Daniil Harms's peculiarly normative poetics. Attention is paid to the domineering factor of the writer's work - the category of zaum, on the basis of which the characters' world is built. The author-character-reader relationships are extremely specific. Harms's works are filled with phantasmagoria and destruction, both in terms of phonetic-graphic, lexical-semantic, and situational aspects. Through desemantization, illogism and absurdity of everything and everyone, Harms brings his character and the world around him to liberation from the "mundane husk" and closer to God, to selfknowledge. Deconstruction (destruction), which characterizes an abstruse text, is the basic principle of Daniil Harms's texts. Harms's striving for zaum at the language level is reflected, in particular, in the use of onomastic vocabulary, anthroponyms, a large number of neologisms (even within the same text), semantic and syntactic nonsense, spelling and punctuation deviations; at the level of plot - it is the use of completely ridiculous situations, caricature and de-individualization. In Harms's works, all sorts of deviations from linguistic norms and rules do not destroy the text, do not lead to the system destruction, but reveal the creative potential of the linguistic artist.
\end{abstract}

Keywords: text by D. Harms, desemantization, anthroponyms, neologisms, idiostyle.

Статья посвящена рассмотрению текста в русле своеобразно-нормативной поэтики Даниила Хармса. Внимание уделяется доминанте творчества писателя - категории зауми, на основе которой выстраивается мир персонажей текстов. Отношения автор-персонаж-читатель предельно специфичны. Хармс зачастую предлагает своему читателю произведения, наполненные фантасмагорией и разрушением как в плане, например, фонетико-графическом, лексико-семантическом, так и в плане ситуативном. Посредством десемантизации, алогизма и абсурдизации всего и всех Хармс выводит своего персонажа и мир вокруг на новый уровень, уровень освобождения от «мирской шелухи» и приближения к Богу, к самопознанию. Деконструкция (разрушение) - основной принцип текстов Даниила Хармса, составляющая заумного текста. Стремление Хармса к зауми на уровне языка отражено, в частности, в использовании ономастической лексики, антропонимов, большого числа неологизмов (даже в рамках одного текста), семантической и синтаксической бессмыслицы, орфографической и пунктуационной девиации, на уровне сюжета - в использовании совершено нелепых ситуаций, карикатурности и деиндивидуализации персонажей. Разного рода отклонения от языковых норм и правил в текстах Хармса не разрушают текст, не приводят к деструкции системы, но раскрывают творческий потенциал лингвохудожника.

Ключевые слова: текст Д. Хармса, десемантизация, антропонимы, неологизмы, идиостиль.

Мир Хармса - фантасмагория, искусно соединяющая здравый разум и безудержное алогичное. С одной стороны, умение мастерски симулировать психическое заболевание, шизофрению, чтобы укрыться от мобилизации в условиях военного периода (1940-е гг.), с другой - поразительная способность создавать тексты, полные хаоса и трагизма, будучи человеком вполне здоровым и рассудительным. Настолько трудно подчас провести границу между реальным и выдуманным, между безумием и яркой индивидуальностью, неординарной личностью автора.

С точки зрения лингвистики предстает широкое поле для исследования текстового контента 
этого экстравагантного поэта, драматурга, писателя-авангардиста XX века, мир которого перевернут и в плане содержания, и в плане формообразования. Особенно ранние произведения (до 1930 г.) наполнены разрозненными фразами, создающими ощущение соединения несоединимого, лексического хаоса и синтаксической несоразмерности, например, в тексте «В кружок друзей камерной музыки»:

\section{Неходите января \\ скажем девять - говоря \\ выступает Левый Фланг \\ - это просто не хорошо. - \\ и панг ${ }^{1}$ [Хармс, т.1, с. 67]}

Текст словно разрывается на полуслове, словно остается незаконченным, незавершенным, однако в этом и следует увидеть парадоксальность хармсовской мысли, направляющей нас к созданию новой реальности, нового смысла. Бессмыслица семантического и синтаксического плана только кажущаяся, видимая, лежит в основе глубоких воззрений писателя, основанных на отличном знании философских учений, истории искусств, увлечении нумерологией. Наложило свой отпечаток и увлечение авангардным искусством, поэзией футуризма, основными константами которых являлось неприятие всего «академического», традиционного, «старого», стремление к гибридизации жанров и сознательная установка на эпатаж, антиэстетизм. Созданная им и его другом Александром Введенским творческая группа Объединение реального искусства (ОБЭРИУ) в литературе выдвигает абсурд как доминанту лингвоэстетики, что наблюдаем, в частности, в репрезентации ономастикона текстов самим Даниилом Хармсом. Он обращается к антропонимам, широко распространенным в русском обществе, в контексте произведения происходит их десемантизация, обессмысливание, что логично приводит к деиндивидуализации человека, персонажа: Алексей Алексеевич Алексеев («Рыцарь»), Николай Иванович Серпухов («О явлениях и существованиях»), Иван Иванович и Петр Николаевич («Елизавета Бам»), Андрей Семенович («Математик»), Андрей Семенович и Петр Павлович («История сдыгр аппр»), Андрей Андреевич («Новый талантливый») и многие другие.

В то же время Хармс не обошёл стороной и антропонимы, либо необычные своей звуковой оболочкой, к примеру, Елизавета Бам - звукоподражание («Елизавета Бам»), либо отвечающие за происхождение: Ольга Форш - нем. или

\footnotetext{
1 Здесь и далее сохранены орфография и пунктуация автора $-Л$. $A$.
}

евр. («Ольга Форш подошла к Алексею Толстому»), либо придуманные самим автором: Абрам Демьянович Пентопасов («История»), Фадеев, Калдеев и Пепермалдеев («Фадеев, Калдеев и Пепермалдеев») и др.

Как видим, актуально употребление Хармсом трехчленных и двучленных (в словообразовательном отношении) антропонимических единиц, и, несмотря, в большинстве случаев, на вполне традиционные имена и с точки зрения структуры, и с точки зрения этимологии, их носители - персонажи - в игровой манере десемантизируют и пространство вокруг, и человеческие отношения, и самих себя: в одном из случаев (цикл коротких рассказов «Случаи») смерть настигает нескольких персонажей друг за другом («Четыре иллюстрации того, как новая идея огорашивает человека»); в рассказе «Сказка» человек по фамилии Семенов пошел гулять, сел на камушек и заснул; а в рассказе «Упадание», пока с крыши падали два человека, две женщины с одинаковым именем Ида Марковна, являющиеся свидетелями происшествия, совершали алогичные в данной ситуации действия: сморкалась в стакан, содрала с себя рубашку и начала этой рубашкой скорее протирать запотевшее оконное стекло; высунувшись в окно, визжали и били ногами. Сон и смерть - доминирующие мотивы в абсурдно-реальном творчестве Хармса - следует рассматривать как способы освобождения (от жизни, проблем, страхов, тоски), подобное наблюдаем и в отношении языка, когда деструкция на разных языковых уровнях приводит к семантическому вакууму.

Стремление Хармса к речетворчеству, зауми наблюдаем, в частности, в стихотворении «Говор», где ярко представлено использование неологической лексики как характерной особенности заумного словотворчества писателя:

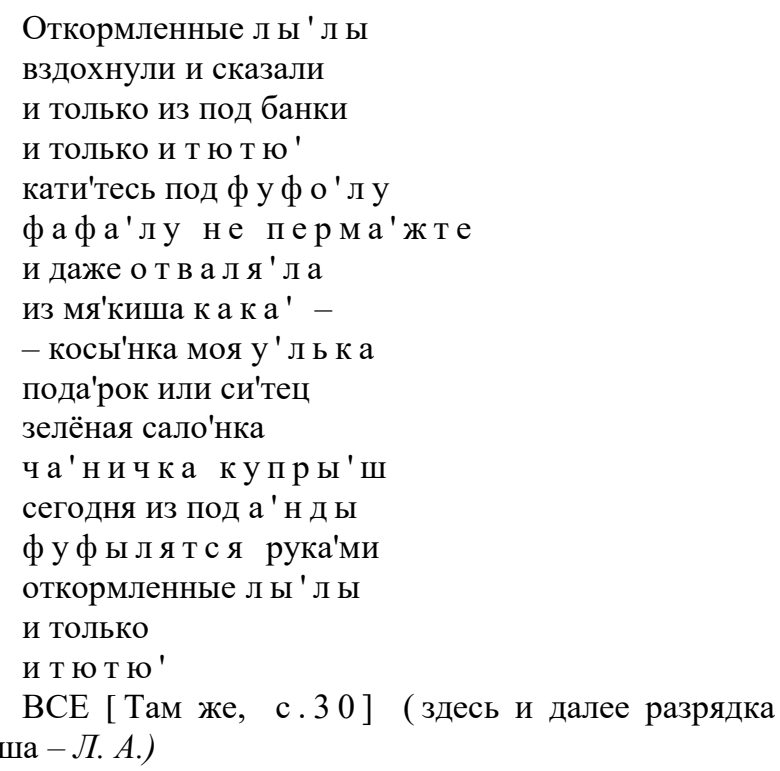


Причем можно говорить о наличии либо только лексического значения неологизмов, либо только грамматического значения, как в предыдущем примере.

По метким словам Николая Бердяева, представителя русского экзистенциализма, «в футуризме погибает человек, как величайшая тема искусства. < ..> человек разорван в клочья. Все начинает входить во все. Все реальности в мире сдвигаются с своего индивидуального места. В человека начинают входить предметы, лампы, диваны, улицы, нарушая целостность его существа, его образа, его неповторимого лика» [Бердяев, с. 122]. И как же точно подобная ситуация наблюдается в притче Хармса «Кирпич»:

Господин невысокого роста с камушком в глазу подошел к двери табачной лавки и остановился. Его черные, лакированные туфли сияли у каменной ступенечки, ведущей в табачную лавку. Носки туфель были направлены вовнутрь магазина. Еще два шага, и господин скрылся бы за дверью. Но он почему-то задержался, будто нарочно для того, чтобы подставить голову под кирпич, упавший с крыши. Господин даже снял шляпу, обнаружив свой лысый череп, и, таким образом, кирпич ударил господина прямо по голой голове, проломил черепную кость и застрял в мозгу. Господин не упал. Нет, он только пошатнулся от страшного удара, вынул из кармана платок, вытер им лицо, залепленное кровавыми мозгами...[Кирпич. Притча от Даниила Хармса]:

Как правило, художественное пространство и персонаж, «живущий» в нем, неразрывно связаны. Так, можно говорить о языковой личности со своим речевым поведением и социальнопсихологическим типом. Что мы видим у Даниила Хармса?

Он, несомненно, продуманно подходит к отбору языкового материала с целью моделирования персонажа, но целесообразно ли говорить о личности со своей жизненной позицией? Обратимся к рассказу «Смерть старичка»:

У одного старичка из носа выскочил маленький шарик и упал на землю. Старичок нагнулся, чтобы поднять этот шарик, и тут у него из глаза выскочила маленькая палочка и тоже упала на землю. Старичок испугался и, не зная, что делать, пошевелил губами. В это время у старичка изо рта выскочил маленький квадратик. Старичок схватил рот рукой, но тут у старичка из рукава выскочила маленькая мышка. Старичку от страха сделалось нехорошо, и он, чтобы не упасть, сел на корточки. Но тут в старичке что-то хрустнуло, и он, как мягкая плюшевая шуба, повалился на землю [Хармс, т. 2, с. 160].
Персонаж Д. Хармса - «условный», с возможностью трансформироваться во что угодно, не личность, а «недочеловек» [Друскин, с. 117]. Жизнь человека, по мнению Хармса, бессмысленна, в связи с этим автор отнимает жизнь у своего персонажа играючи, помещая его в ситуацию гротеска и абсурда.

Гротескно-абсурдная форма представления материала пестрит орфографическими и пунктуационными девиациями (пропуск знаков препинания, прописные буквы, замена одной или нескольких букв в слове и пр.), что следует считать продуманным авторским приемом. По мнению обэриутов, слово, написанное в соответствии с правилами, есть слово мертвое, неподвижное. Так, Хармс считал, что освобождение слова от «шелухи», «оболочки» раскроет истинный смысл его, поможет познать, что у каждого человека (читателя) свое собственное мироощущение, видение мира.

Знакомые с творчеством Даниила Хармса осведомлены о том, что Хармс восхищался Велимиром Хлебниковым, одним из крупнейших деятелей русского авангарда, считая его своим учителем.

Хлебников утверждает, что «есть путь сделать заумный язык разумным» [Хлебников, с. 234]. Речь идет о том, чтобы осознать то значение, которое каждый звук несет в себе. Следует отметить, что творчество Даниила Хармса подчинено единственному: уйти от классического языкового канона и через заумь и кажущуюся бессмыслицу прийти к совершенно новому смыслу. Таким образом в текстологии Хармса рождается новый язык, язык, творящий новую реальность. К тому же, углубляясь в речетворчество Хармса, можно вспомнить установки обэриутов о том, что искусство это, прежде всего, то, что способно раскрыть глаза на мир, искусство не должно и не может подчиняться устоявшимся законам жизни, общества. И Хармс органично вписывался в рамки данных умозаключений, искусно создавая свою художественноэстетичную реальность, восходящую к русской религиозности. Разного рода отклонения от языковых норм и правил в текстах Хармса не разрушают текст, не приводят к деструкции системы, но раскрывают творческий потенциал лингвохудожника. Таким образом, можно говорить о логичной конструктивности лингвистических аномалий.

\section{Список литературы}

Бердяев Н. А. Смысл истории. Опыт философии человеческой судьбы. Москва: Юрайт, 2018. 175 с. 
Друскин Я. С. Звезда бессмыслицы // «Собрание друзей, оставленных судьбою: А. Введенский, Л. Липавский, Я. Друскин, Д. Хармс, Н. Олейников: «чинари» в текстах, документах и исследованиях: В 2 т. Т. 1. М.: Ладомир. 2000. 846 с.

Кирпич. Притчи от Даниила Хармса. // Притчи. Py. URL: https://pritchi.ru/id_4186 (дата обращения: 29.09.2020)

Хармс Д. Собрание сочинений: в 3 т. Т. 1. Авиация превращений. СПб.: Азбука, 2000. 576 с.

Хармс Д. Собрание сочинений: в 3 т. Т. 2. Новая анатомия. СПб.: Азбука, 2000. 416 с.

Хлебников B. Наша основа. Собрание произведений Велимира Хлебникова. Т. 1-5. Под ред. Ю. Тынянова и Н. Степанова. Л., Изд-во писателей в Ленинграде, 1928-1933. Т. 5. 1933. 234 с..

\section{References}

Berdiaev, N. A. (2018). Smysl istorii. Opyt filosofii chelovecheskoi sud'by [The Meaning of History. The Experience of the Human Destiny Philosophy]. 175 p. Moscow, Iurait. (In Russian)

\author{
Ахметзянова Лиана Михайловна, \\ кандидат филологических наук, \\ доцент, \\ Казанский федеральный университет, \\ 420008, Россия, Казань, \\ Кремлевская, 18. \\ lianaorx@rambler.ru
}

Druskin, Ya. S. (2000). Zvezda bessmyslitsy [The Star of Nonsense]. Sborishche druzei, ostavlennykh sud'boiu: A. Vvedenskii, L. Lipavskii, Ya. Druskin, D. Harms, N. Oleinikov: "chinari" v tekstakh, dokumentakh i issledovaniyakh: V 2-kh t. T. 1.846 p. Moscow, Ladomir. (In Russian)

Harms, D. (2000). Sobranie sochinenii: v 3 t. T. 1. Aviatsiia prevrashchenii [Collected Works: In 3 vol. Vol. 1. Transformations of Aviation]. 576 p. St. Petersburg, Azbuka. (In Russian)

Harms, D. (2000). Sobranie sochinenii: v 3 t. T. 2. Novaia anatomiia [Collected Works: 3 t. T. 2. New Anatomy]. 416 p. St. Petersburg, Azbuka. (In Russian)

Hlebnikov, V. (1933). Nasha osnova. Sobranie proizvedenij Velimira Hlebnikova [Our Foundation. Collection of Works by Velimir Khlebnikov]. T. 1- 5. Pod red. Ju. Tynianova i N. Stepanova. T. 5. 234 p. Leningrad, Izd-vo pisatelei v Leningrade. (In Russian)

Kirpich. Pritchi ot Daniila Kharmsa [Daniel Harms's Proverbs]. Pritchi. Ru. URL: https://pritchi.ru/id_4186 (accessed: 29.09.2020). (In Russian)

The article was submitted on 07.10.2020

Поступила в редакцию 07.10.2020

\author{
Akhmetzyanova Liana Mikhailovna, \\ Ph.D. in Philology, \\ Associate Professor, \\ Kazan Federal University, \\ 18 Kremlyovskaya Str., \\ Kazan, 420008, Russian Federation. \\ lianaorx@rambler.ru
}

